ROCZNIKI NAUK PRAWNYCH

Tom XXX, numer $4-2020$

DOI: https://doi.org/10.18290/rnp20304-7

\title{
ORGANIZACJA \\ SKUTECZNEJ W DZIAŁANIU INSTYTUCJI PUBLICZNEJ NA PRZYKŁADZIE DZIAŁANIA RZECZNIKA PRAW DZIECKA*
}

\section{WPROWADZENIE}

Temat niniejszego opracowania dotyczy określenia sprawnego działania na przykładzie instytucji publicznej, jaką jest Rzecznik Praw Dziecka (RPD) - o charakterze ombudsmańskim.

Sprawność jest pojęciem wieloznacznym, trudnym do zdefiniowania, w języku potocznym oznacza biegłość lub zręczność w działaniu, szybkość, efektywność itp. T. Kotarbiński ${ }^{1}$, a w ślad za nim inni badacze prakseologii i organizacji posługują się tym pojęciem. Z prakseologicznego punktu widzenia ${ }^{2}$ sprawność utożsamiana jest ze skutecznością, korzystnością, efektywnością ${ }^{3}$. W sensie uniwersalnym to, oprócz wymienionych zalet, dokładność, niezawodność i prostota. Skutecznym działaniem jest takie działanie, które prowadzi do skutku zamierzonego

Dr PATRYCja SoŁtYSIAK - adiunkt, Katedra Prawa Administracyjnego i Finansowego, Wydział Prawa i Ekonomii Uniwersytetu Humanistyczno-Przyrodniczego im. Jana Długosza w Częstochowie, ul. Zbierskiego 2/4, 42-200 Częstochowa; e-mail: p.soltysiak@ujd.edu.pl. ORCID: https://orcid.org/ 0000-0001-9544-0671.

* Artykuł powstał na podstawie referatu wygłoszonego na Konferencji Naukowej pt. „Aktualne problemy prawodawstwa w krajach Europy Środkowo-Wschodniej” w ramach IV Środkowoeuropejskiego Forum Prawno-Administracyjnego, która odbyła się w dniach 17-18 października 2019 r. w Zakopanem.

${ }^{1}$ Zob. T. KOTARBIŃSKI, Traktat o dobrej robocie, Wrocław: Wydawnictwo Uniwersytetu Łódzkiego 1969, s. 120 n.

${ }^{2}$ Prakseologia jest teorią sprawnego działania. To dziedzina badań naukowych dotycząca wszelkiego, celowego działania ludzkiego. Stownik języka polskiego, red. M. Szymczak, t. II, Warszawa: Państwowe Wydawnictwo Naukowe 1979, s. 907.

${ }^{3}$ Por. L.J. ŻUKowsKi, Spoteczna skuteczność prawa administracyjnego, Rzeszów-Przemyśl: Wydawnictwo Wyższej Szkoły Prawa i Administracji 2015, s. 117 n.; J. SuPERnAT, Odestania do zasad prakseologicznych $w$ prawie administracyjnym, „Acta Universitatis Wratislaviensis. Przegląd Prawa i Administracji”, Prawo, 1984, nr 763, s. 1. 
jako cel. Z kolei cel jest to wyobrażony, przyszły stan rzeczy lub procesu, który ma być osiągnięty w wyniku tego działania. Działanie prowadzi do celu, gdy umożliwia lub ułatwia jego osiągnięcie, albo gdy pozwala na jego całkowite lub częściowe uzyskanie. Konsekwencją przyjętego założenia jest ocena skuteczności, która zależy od sposobu sformułowania celu. Miarą skuteczności działania jest stopień osiągnięcia celu, a ściślej mówiąc: stopień zbliżenia się do osiągnięcia wszystkich końcowych celów działania, czyli celu głównego i ewentualnych celów ubocznych. Każdemu działaniu bowiem przypisuje się wielość celów, wśród których można wyróżnić co najmniej cel główny i cele uboczne (cząstkowe). Natomiast wszystkie działania można sklasyfikować biorąc pod uwagę stopień osiągnięcia celu (czyli skuteczności). Skala skuteczności działań jest stopniowalna. Działania ze względu na jego założony cel mogą być: 1) całkowicie skuteczne; 2) częściowo skuteczne; 3) nieskuteczne; 4) przeciwskuteczne; 5) obojętne.

Zasady i wytyczne sprawnej organizacji działania stanowią zbiór proponowanych przez naukę dyrektyw i zaleceń, których świadome stosowanie w znacznym stopniu ułatwia i przyspiesza działanie oraz pozwala na osiągnięcie lepszych wyników. Cechuje je pewnego rodzaju uniwersalizm, dzięki któremu można je stosować z powodzeniem na gruncie nauk prawnych, jak również w naukach organizacji zarządzania. Rozważania nad skutecznością działania prowadzą do przekonania, iż dobra - skuteczna - organizacja pozwala na działania wysoce efektywne. Istotnym elementem skuteczności jest zjawisko synergii, polegające na współdziałaniu, koordynacji, współpracy organizacyjnej, zespołowej. Współdziałanie daje lepszy efekt, prowadzi skuteczniej do zamierzonego celu niż pojedyncze, jednostkowe działanie. Założenia te można uzupełnić Arystotelesowską tezą, że „całość to więcej niż suma części”. Problematyka skuteczności działania pojmowana jest jako aktywność wskazująca na osiągnięcie zamierzonych celów.

\section{MODEL DZIAŁANIA RZECZNIKA PRAW DZIECKA}

$A b$ initio rozważając kształt organizacyjny instytucji Rzecznika Praw Dziecka, należy ustalić charakter jego działań i ich zakres, który dotyczy kontroli działań i zaniechań organów władzy publicznej sprawowanej z punktu widzenia kryterium legalności. Jego działania zatem mają charakter związany z różnymi wadliwościami funkcjonowania organów państwa. Rzecznik Praw Dziecka to

\footnotetext{
${ }^{4}$ ARYSTOTELES, Metafizyka, edycja internetowa, http://s.lubimyczytac.pl [dostęp: 12.09.2019].
} 
instytucja o charakterze ombudsmańskim, to podmiot mający szczególny autorytet, niezależny od innych podmiotów państwa, podlegający parlamentowi i w swych działaniach przyczyniający się do prawa do dobrej administracji. Informuje parlament i opinię społeczną o stanie przestrzegania praw dziecka i o funkcjonowaniu administracji w tym zakresie (zarówno podmiotowym, jak i przedmiotowym).

Dla ustalenia modelu działania Rzecznika Praw Dziecka należy wskazać, że Polska, podobnie jak większość krajów na świecie, posiada organy o charakterze ombudsmańskim lub quasi-ombudsmańskim w postaci różnych zinstytucjonalizowanych rzeczników praw, których powinna cechować skuteczność działania. Należy zatem przyjąć, iż „organy te tworzą rodzaj sieci”. Etymologia nazwy tej instytucji wywodzi się z języka szwedzkiego i oznacza przedstawiciela, pełnomocnika, zastępcę ${ }^{5}$.

Utworzenie w polskim porządku prawnym instytucji Rzecznika Praw Dziecka było poprzedzone dyskusją społeczną i parlamentarną, która z jednej strony wskazywała na zalety tej instytucji, a z drugiej na słabości. Próbowano uchwycić istotę, pole działania, charakter, funkcje tej instytucji, która z powodzeniem występowała w wielu krajach Europy i świata od wielu lat ${ }^{6}$.

Problem ochrony praw poszczególnych grup społecznych istnieje na całym świecie. Niezależnie od ich regulacji, w poszczególnych krajach powoływani są ombudsmani stojący na straży praw człowieka. Dlatego istotne jest sprawne i efektywne funkcjonowanie w prawie wewnętrznym podmiotu sprawującego odpowiednią kontrolę, czy prawa człowieka są należycie wykonywane, zabezpieczone i chronione. Do takich podmiotów należy ombudsman, którego odpowiednikiem jest Rzecznik Praw Dziecka.

W powszechnym przekonaniu urząd Rzecznika (ombudsmana) jest przydatny, ponieważ bardzo często społeczeństwo potrzebuje umocowanej instytucji prawnej o charakterze kontrolnym, niezawisłej i niezależnej, która w przypadku naruszenia dobra, praw i wolności poszczególnych grup społecznych interweniowałaby $w$ ich obronie na skutek np. bezczynności czy też niewłaściwego działania za strony organów i instytucji państwowych. Instytucje ombudsmańskie powstały więc w celu zapewnienia ochrony przed naruszeniami ze strony organów państwowych.

5 Stownik szwedzko-angielski, http://lexin.nada.ktnse/swe-eng.html,http://www.etaco.com/ english-swedish-dicionary/?refid=36591 [dostęp: 12.05.2017].

${ }^{6}$ Szerzej na ten temat zob. P. SOŁTYSIAK, Rzecznik Praw Dziecka. Zagadnienia ustrojowoprawne, Warszawa: Wydawnictwo Difin 2019, s. 23 n. 
Zaznaczyć należy, iż każda próba spojrzenia na konkretną instytucję prawną, jeżeli nie ma być obarczona zarzutem metodologicznej niepoprawności, wymaga w sposób zasadniczy określenia badanego przedmiotu, podstaw badań metodologicznych oraz struktury pojęciowej, którą będziemy się posługiwać w trakcie dalszych rozważań ${ }^{7}$.

Status prawny Rzecznika w państwie zawarty jest w art. 72 ust. 4 Konstytucji RP ${ }^{8}$, która odsyła do ustawy o Rzeczniku Praw Dziecka ${ }^{9}$, określającej sposób jego działania.

W celu ustalenia charakteru instytucji RPD należy podać cechy, jakie ona posiada z punktu widzenia doktrynalnych kwalifikacji. Istotne jest to, że pomimo względnie stabilnej jej regulacji prawnej, uległa ona na przestrzeni kilkunastu lat rozwojowi zgodnemu z kierunkami wyznaczanymi przez standardy międzynarodowe, a w związku z tym trzeba wskazać, jakie konkretnie czynniki miały wpływ na modyfikację tej instytucji.

Określenie istoty jakiegoś pojęcia, które może być ujmowane w różnych płaszczyznach odniesienia, wymaga zastosowania wielu narzędzi wykładni i dokonywania wnioskowań prawniczych, których rezultaty nie zawsze prowadzą do jednoznacznego stanowiska. Wynika to między innymi $\mathrm{z}$ różnych punktów widzenia istoty oraz umiejscowienia instytucji ombudsmańskiej w polskim porządku prawnym, jako podmiotu wyodrębnionego organizacyjnie w ramach struktury państwa z własnym schematem działania.

Stawiam tezę, iż RPD jest instytucjonalnym modelem ombudsmana o własnym zakresie kompetencji, przysługującej mu jako podmiotowi prawa powołanemu do ochrony praw i dobra dziecka, czyli pewnej zindywidualizowanej grupy społecznej.

Rzecznik jako organ kontroli zewnętrznej nad administracją bierze udział w postępowaniach innych organów państwa i sam prowadzi działania, których celem jest „stanie na straży” praw i dobra dziecka. Aktywności RPD związane są ściśle z normami prawa administracyjnego, które należy do grupy gałęzi prawa publicznego i odnosi się do realizacji interesu publicznego. Rzecznik podejmując czynności prawne, musi podać ich wyraźną podstawę prawną. Jego działania mogą mieć charakter tak zewnętrzny - wystąpienia generalne, jak i wewnętrzny - wydawanie poleceń służbowych, wytycznych pracownikom Biura RPD. Sprawy, które podejmuje, przybierają formę indywidualną - to działania w zakresie ochrony zagrożonego prawa konkretnego, indywidualnego

\footnotetext{
${ }^{7}$ Zob. T. Woś, Moc wiążaca aktów administracyjnych w czasie, Warszawa: Państwowe Wydawnictwo Naukowe 1978, s. 5.

${ }^{8}$ Konstytucja RP z dnia 2 kwietnia 1997, Dz.U. Nr 78, poz. 483 ze sprost. i zm.

${ }^{9}$ Ustawa z dnia 6 stycznia 2000 r. o Rzeczniku Praw Dziecka, t. jedn.: Dz.U. 2017, poz. 922.
} 
dziecka, lub formę generalną - to działania nakierowane na ochronę zbiorowych praw dzieci.

Rzecznik Praw Dziecka korzysta z prawnego rodzaju działania, które z punktu widzenia prawa administracyjnego jest przykładem czynności o charakterze niewładczym; są to czynności kontroli niezawierające w swych treściach możliwości wiążącego oddziaływania na aktywność podmiotów poddanych kontroli. Głównym celem i zarazem zadaniem kontroli jest wykrywanie błędów i sygnalizowanie o nich w działaniu różnych podmiotów prawa. Rzecznik kontroluje i bada, czy organy, organizacje lub instytucje właściwie stosują obowiązujące przepisy w zakresie ochrony praw i dobra dziecka, a w razie wątpliwości odpowiednio reaguje, mianowicie poprzez żądanie złożenia wyjaśnień, udzielenia informacji, udostępnienie akt, dokumentów, ponadto może zgłosić swój udział w postępowaniach sądowych na prawach przysługujących prokuratorowi.

Działania kontrolne RPD, polegające na sprawdzaniu i ocenianiu funkcjonowania aparatu administracyjnego, uzasadniają traktowanie go jako jednej z instytucji kontroli zewnętrznej administracji oraz instytucji ochrony prawa. Przedmiotem kontroli sprawowanej przez Rzecznika jest sprawdzanie zarówno działań, jak i zaniechań, czyli bezczynności innych podmiotów prawa. Prawną formą działania RPD jest również szeroko rozumiana współpraca z aparatem administracyjnym.

\section{SKUTECZNOŚĆ DZIAŁANIA RZECZNIKA PRAW DZIECKA}

Głównym elementem poruszanej tu tematyki jest zagadnienie skuteczności, rozumianej jako synonim sprawności, racjonalności, doskonalenia i podnoszenia efektywności ${ }^{10}$. Skuteczność to oddziaływanie prawa zgodnie z treścią normy lub celu, który ustawodawca zamierzał osiągnąć. W tym kontekście niezwykle istotna jest kwestia autorytetu prawa jako warunku koniecznego do wzbudzania respektu dla norm prawnych. W teorii prawa skuteczność działania przepisów prawnych bywa przywoływana w celu empirycznego przetestowania istnienia i tożsamości systemu prawnego. Test ten składa się z trzech głównych i wzajemnie zależnych składników: skuteczności działania, charakteru instytucjonalnego oraz źródeł prawa ${ }^{11}$.

${ }^{10}$ Zob. J. Starościak, Problemy wspótczesnej administracji, Warszawa: Wydawnictwo Wiedza Powszechna 1972, s. 26; J. KoRCZAK, O pojęciu sprawności administracji, RzeszówPrzemyśl: Wydawnictwo Wyższej Szkoły Prawa i Administracji 2011, s. 456-488.

${ }^{11}$ Zob. L.J. ŻukowsKi, Spoteczna skuteczność prawa, s. $80 \mathrm{n}$. 
Zagadnienie skuteczności na gruncie nauk prawnych od lat absorbuje uwagę badaczy. In genere prawo powinno być skuteczne, tak jak i podmioty, które je stanowią i stosują. Skuteczne prawo to „dobre prawo”, rozumiane jako środek realizacji ustalonych i modyfikowanych celów nawiązujących do ocen i norm tworzących system prawny, jak również do określonego światopoglądu, przyjmowanych zasad, np. etycznych, moralnych, społecznych itp.

Na skuteczną możliwość działania RPD wpływa odpowiednie zaplecze materialne, w postaci budżetu na działalność oraz różne inicjatywy promocyjne, prowadzone badania, ankiety, organizowane seminaria naukowe dotyczące poszczególnych kategorii ochrony praw dziecka w Polsce. Ponadto, jednym z czynników sprawnego i skutecznego funkcjonowania instytucji jest stworzenie wewnętrznego schematu organizacyjnego, który będzie łączył różne elementy składowe pozwalające wydobyć wzajemne zależności między nimi i będzie służył do zarządzania całą instytucją zorganizowaną formalnie ${ }^{12}$. Model sprawnego i skutecznego działania wyznacza normy, w obrębie których można analizować uzyskane informacje, dostarcza sprawnej procedury pozwalającej wykorzystywać informacje i podejmować decyzje w określonej dziedzinie, ułatwia odrzucenie danych niemających bezpośredniego związku z daną sprawą, pozwala podmiotowi stosującemu prawo określić zakres najważniejszych danych wiążących się z rozważaną sytuacją ${ }^{13}$.

\section{PODSUMOWANIE}

W ostatnich latach zauważyć można stale powiększającą się liczbę podmiotów o charakterze ombudsmańskim, które mają ściśle określony zakres podmiotowy i przedmiotowy spraw, jakimi się zajmują. Są to wyspecjalizowane podmioty ochrony wolności i praw poszczególnych grup społecznych, podmioty o charakterze kontrolnym, których działania mają zmierzać do realizacji prawa do dobrej administracji. Podmioty te powinny zapewniać ustalone standardy w zakresie stosowania norm prawnych i dawać adresatom tych norm bezpieczeństwo prawne, chronić ich interesy i odpowiednio reagować, zgodnie z zakresem swych kompetencji, wówczas gdy zaistnieje uzasadniona obawa naruszenia ich praw.

RPD jest sprawnie, skutecznie i efektywnie działającą instytucją prawną. Rzecznik spełnia wymogi jako organ państwa na podstawie przepisów Konstytucji RP,

\footnotetext{
${ }^{12}$ P. SoŁtysiak, Rzecznik Praw Dziecka, s. 247.

${ }^{13}$ Zob. T. LAMBERT, Problemy zarzadzania, Warszawa: Wydawnictwo Dom Wydawniczy ABC 1999, s. 33 n.
} 
Konwencji o Prawach Dziecka i ustawy o Rzeczniku Praw Dziecka, skutecznie chroni interesów wyodrębnionej grupy społecznej i współdziała z innymi podmiotami prawa $\mathrm{w}$ zakresie ochrony praw i dobra dziecka w Polsce, ale również w Europie i na świecie. W moim przekonaniu nie jest on instytucją fasadową, lecz sprawnie i skutecznie działającym organem, przyczyniającym się do poprawy praw dzieci.

Dokonana analiza wskazuje na rosnące zainteresowanie tego typu instytucją w różnych rejonach Europy i świata. Popularność idei ombudsmana nie pozostała bez wpływu na polskie środowiska polityczne i prawnicze. Spowodowało to zainicjowanie dyskusji o utworzeniu w pierwszej kolejności Rzecznika Praw Obywatelskich, a następnie Rzecznika Praw Dziecka na wzór regulacji standardów światowych. Na wprowadzenie instytucji RPD do polskiego porządku prawnego znaczący wpływ miały też wewnętrzne przekonania o potrzebie wyłonienia w ramach obowiązującego systemu prawnego reprezentanta, którego celem będzie ochrona praw dziecka na szczeblu centralnym. Odbywały się różne dyskusje publiczne o tym, jak ma wyglądać jego struktura organizacyjna, status prawny i pozycja ustrojowoprawna.

\section{BIBLIOGRAFIA}

ARYstoteles: Metafizyka, edycja internetowa, http://s.lubimyczytac.pl [dostęp: 12.09.2019].

KoRCZAK Jerzy: O pojęciu sprawności administracji, Rzeszów-Przemyśl: Wydawnictwo Wyższej Szkoły Prawa i Administracji 2011.

KOTARBIŃSKI Tadeusz: Traktat o dobrej robocie, Wrocław: Wydawnictwo Uniwersytetu Łódzkiego 1969.

LAMBERT Tom: Problemy zarządzania, Warszawa: Dom Wydawniczy ABC 1999.

Słownik szwedzko-angielski, http://lexin.nada.ktnse/swe-eng.html,http://www.etaco.com/englishswedish-dicionary/?refid=36591 [dostęp: 12.05.2017].

Słownik języka polskiego, red. M. Szymczak, t. II, Warszawa: Państwowe Wydawnictwo Naukowe 1979.

SoŁtysiak Patrycja: Rzecznik Praw Dziecka. Zagadnienia ustrojowoprawne, Warszawa: Wydawnictwo Difin 2019.

SUPERNAT Jerzy: Odesłania do zasad prakseologicznych w prawie administracyjnym, „Acta Universitatis Wratislaviensis. Przegląd Prawa i Administracji”, Prawo, 1984, nr 763.

StArościaK Jerzy: Problemy współczesnej administracji, Warszawa: Wydawnictwo Wiedza Powszechna 1972.

Woś Tadeusz: Moc wiążąca aktów administracyjnych w czasie, Warszawa: Państwowe Wydawnictwo Naukowe 1978.

ŻuKowski Lech J.: Społeczna skuteczność prawa administracyjnego, Rzeszów-Przemyśl: Wydawnictwo Wyższej Szkoły Prawa i Administracji 2015. 


\title{
ORGANIZACJA \\ SKUTECZNEJ W DZIAŁANIU INSTYTUCJI PUBLICZNEJ \\ NA PRZYKŁADZIE DZIAŁANIA RZECZNIKA PRAW DZIECKA
}

\begin{abstract}
Streszczenie
Zasady i wytyczne sprawnej organizacji działania stanowią zbiór proponowanych przez naukę dyrektyw i zaleceń, których świadome stosowanie w znacznym stopniu ułatwia i przyspiesza działanie oraz pozwala na osiągnięcie lepszych wyników. Problem ochrony praw poszczególnych grup społecznych istnieje na całym świecie. Polska, podobnie jak większość krajów na świecie, posiada organy o charakterze ombudsmańskim lub quasi-ombudsmańskim w postaci różnych zinstytucjonalizowanych rzeczników praw, których powinna cechować skuteczność działania. Istotne jest sprawne i efektywne funkcjonowanie w prawie wewnętrznym podmiotu sprawującego odpowiednią kontrolę, czy prawa poszczególnych grup społecznych są należycie wykonywane, zabezpieczone i chronione. Do takich podmiotów należy ombudsman, którego odpowiednikiem jest RPD. Przedmiotem kontroli sprawowanej przez Rzecznika jest sprawdzanie zarówno działań, jak i zaniechań, czyli bezczynności innych podmiotów prawa. Prawną formą działania RPD jest również szeroko rozumiana współpraca z aparatem administracyjnym.
\end{abstract}

Słowa kluczowe: Rzecznik Praw Dziecka; ombudsman; prawa dziecka; ochrona; skuteczność; efektywność działania

\section{ORGANIZATION OF AN EFFECTIVE PUBLIC INSTITUTION ON THE EXAMPLE OF THE OMBUDSMAN FOR CHILDREN}

\section{Summary}

Principles and guidelines for efficient organization of operation constitute a set of directives and recommendations proposed by science, the conscious application of which - purposeful application significantly facilitates and accelerates operation and allows for achieving better results. The problem of protecting the rights of individual social groups exists throughout the world. Poland, like most other countries in the world, has ombudsman or quasi-ombudsman bodies in the form of various institutionalized ombudsmen who should be effective. It is important to have efficient, effective functioning in the internal law of the entity exercising appropriate control over whether the rights of individual social groups - human rights are properly exercised, secured and protected. Such entities include the ombudsman, whose counterpart is RPD. The subject of the Ombudsman's control is checking both actions and omissions, i.e. the inaction of other legal entities. The legal form of RPD is also broadly understood cooperation with the administrative apparatus.

Key words: ombudsman for children; ombudsman; children's rights; protection; effectiveness; efficiency actions 